\title{
Trace Metal Concentrations in Zooplankton from the Eastern Arabian Sea and Western Bay of Bengal
}

\author{
G. Rejomon, ${ }^{1}$ K. K. Balachandran, ${ }^{1}$ M. Nair, ${ }^{1}$ T. Joseph, ${ }^{1}$ P. K. Dinesh Kumar, ${ }^{1}$ C. T. Achuthankutty, ${ }^{1}$ \\ K. K. C. Nair, ${ }^{1}$ and N. G. K. Pillai ${ }^{2}$ \\ ${ }^{1}$ National Institute of Oceanography, Regional Centre, Kochi-18, India \\ ${ }^{2}$ Central Marine Fisheries Research Institute, Kochi-18, India
}

\begin{abstract}
Trace metal contents in zooplankton samples were estimated as a part of the Marine Research-Living Resource program at 24 stations in the Bay of Bengal (November, 2002) and 29 stations in the Arabian Sea (September-October, 2003) during the Cruises 209 and 217 of the Fishery and Oceanographic Research Vessel Sagar Sampada. The average metal concentrations in the Bay of Bengal zooplankton (Fe, 14,073 $\mu \mathrm{g} \mathrm{g}^{-1}$; Co, $24.2 \mu \mathrm{g} \mathrm{g}^{-1}$; Ni, $29.5 \mu \mathrm{g} \mathrm{g}^{-1}$; Cu, $46.2 \mu \mathrm{g} \mathrm{g}^{-1} ; \mathrm{Zn}, 2000 \mu \mathrm{g} \mathrm{g}^{-1}$; Cd, $18.7 \mu \mathrm{g} \mathrm{g}^{-1}$; and Pb, $6.55 \mu \mathrm{g} \mathrm{g}^{-1}$ ) were found to be higher of comparable magnitudes than the Arabian Sea zooplankton (Fe, $1786 \mu \mathrm{g} \mathrm{g}^{-1} ; \mathrm{Co}, 14.2 \mu \mathrm{g} \mathrm{g}^{-1} ; \mathrm{Ni}_{1}, 18.6 \mu \mathrm{g} \mathrm{g}^{-1}$; $\mathrm{Cu}, 21.5 \mu \mathrm{g} \mathrm{g}^{-1}$; Zn, $374 \mu \mathrm{g} \mathrm{g}^{-1}$; Cd, $16.5 \mu \mathrm{g} \mathrm{g}^{-1}$; and $\mathrm{Pb}, 4.0 \mu \mathrm{g} \mathrm{g}^{-1}$ ). The spatial variability of metal contents in zooplankton from both basins indicates that it is markedly enriched in coastal samples than offshore samples. The metal enrichment in zooplankton from the coastal areas of the eastern Arabian Sea occurs due to a combined effect of upwelling, riverine, and anthropogenic sources, whereas the latter two are only dominating in the coastal Bay of Bengal zooplankton. A comparison of average trace metal concentrations in the zooplankton from the Arabian Sea and Bay of Bengal showed that the enrichment of $\mathrm{Fe}, \mathrm{Zn}, \mathrm{Cd}, \mathrm{Ni}, \mathrm{Cu}$, and $\mathrm{Pb}$ in the $\mathrm{Bay}$ of Bengal zooplankton may be due to high bioaccumulation factor of these elements, whereas the slight Co enrichment may be due to the bioavailability of this metal in the seawater.
\end{abstract}

Keywords: Arabian Sea, Bay of Bengal, zooplankton, trace metals, bioaccumulation

\section{Introduction}

Trace metals in aquatic systems are distributed over different compartments, such as the dissolved state, colloidal state, and particulate matter (abiotic or biotic), in planktonic and higher organisms. Studies on trace metal distributions and its recycling processes within zooplankton from the Arabian Sea and Bay of Bengal are poorly investigated other than a few reports (George and Kureishy, 1979; Gajbhiye et al., 1985). Zooplankton forms one of the most significant consumers of phytoplankton biomass, of diatoms in particular (Kleppel, 1993). The manner and rate of metal uptake by zooplankton may thus affect its availability to higher organisms. Both phytoplankton and zooplankton may play a role in the biogeochemical cycles of trace metals either by bioaccumulation and later transfer to higher levels or by redistribution (Martin and Knauer, 1973). Zooplankton accumulate metals by direct absorption from water and also by assimilation through food substances (Couture and Kumar, 2003; Chen et al., 2000). Due to their vital role in the food chain of the life in the sea and their relative abundance, they are interesting groups for bioaccumulation studies. Although investigations about the trace metal behavior in the Arabian Sea and Bay of

Received 7 April 2006; accepted 21 February 2006.

Address correspondence to G. Rejomon, National Institute of Oceanography, Regional Centre, Kochi-18, India. E-mail: rejomon2002@yahoo.co.uk
Bengal started in the early 1990s, they are mainly focused on metals in sediments, including their speciation, distribution, and transformation.

India has a long coastal line of more than $8000 \mathrm{~km}$ with an associated continental shelf of 0.5 million $\mathrm{km}^{2}$ and an exclusive economic zone of 2.02 million $\mathrm{km}^{2}$. The coastal zone of the country with its wetlands, lagoons, mangroves, sea-grass beds, coral reefs, and shallow bays, creeks, and estuaries is rich in natural sources. More than 300 million people living in the coastal zone of India are considered to generate $1.11 \times$ $10^{10} \mathrm{~m}^{3}$ of sewage annually; a considerable fraction enters the coastal waters (Zingde, 1999). There is a high concentration of large and medium industries within the narrow coastal belt of $25 \mathrm{~km}$ both the east and west coasts of India. The west coast of India is more industrialized than east coast, with the states of Maharashtra and Gujarat having the largest concentration of industries. A 1994-1995 survey by Central Pollution Control Board (CPCB, 1996) revealed that, of 308 large and medium industries in India, 233 were located along the west coast. These industries are estimated to generate 1.35 million $\mathrm{m}^{3} /$ day of liquid effluents and approximately 34,500 ton/day of solid wastes. In addition, aquaculture farms, largely concentrated in the states of Andhra Pradesh, and Tamil Nadu, generate 2.37 million $\mathrm{m}^{3} /$ day of liquid effluents. A major fraction of these liquid effluents is released to coastal areas presumably untreated and can impart coastal degradation. 
Trace metals in biota natural sources can be used to account for a background exposure, which may be increased by anthropogenic inputs. In assessing environmental quality with respect to heavy metals in seawater, the bioavailable fraction is of major importance, because toxicity depends on the amount absorbed by an organism, itself based on bioavailable exposure concentration. This bioavailable fraction cannot be detected directly by measuring metal concentrations in the soluble phase but can be assessed only by determining the amount of metal incorporated into organisms. Information about trace metal partitioning and distribution in marine organisms has important implications in understanding both elemental bioavailability and the time scales of cycling (Hutchins et al., 1995). Unfortunately, a general picture of metal distribution in and between the various compartments of the surface layer in the Arabian Sea and Bay of Bengal and their bioavailability are not available or are only available to a limited extent compared with other world oceans. Despite the obvious importance of the marine food web to trace metal cycling, it is remarkable that there is so little information in the literature on the trace metal composition of zooplankton in general from the Arabian Sea and Bay of Bengal. In view of this lack of data, zooplankton samples are collected from two geographically close but biogeochemically distinct water masses in which particular attention has been paid to avoiding possible contamination artifacts.

\section{Materials and Methods}

As part of Marine Research-Living Resource program, trace metal distribution in surface seawater and zooplankton of the Bay of Bengal was studied in the Indian exclusive economic zone of the Arabian Sea and Bay of Bengal. The investigation in the Bay of Bengal (Cruise No. 209, November 2002) is based on the samples (Figure 1) along six transects perpendicular to the coast at $11^{\circ} \mathrm{N}, 13^{\circ} \mathrm{N}, 15^{\circ} \mathrm{N}, 17^{\circ} \mathrm{N}, 19^{\circ} \mathrm{N}$, and $20.5^{\circ} \mathrm{N}$ and in the Arabian Sea (Cruise No. 217, September-October 2003) along seven transects at $8^{\circ} \mathrm{N}, 10^{\circ} \mathrm{N}, 13^{\circ} \mathrm{N}, 15^{\circ} \mathrm{N}, 17^{\circ} \mathrm{N}, 19^{\circ} \mathrm{N}$, and $21^{\circ} \mathrm{N}$ (Figure 2). Trace metal studies were performed in all transects at two coastal (50-m depth, inner shelf, and 150-m depth, outer shelf) and at two offshore stations (>1000-m depth). Seawater and zooplankton samples were collected from the surface of each transect in the case of inner shelf, outer shelf, and offshore stations. Zooplankton samples were sampled using a Bongo net (mouth area, $0.28 \mathrm{~m}^{2}$; mesh width, $300 \mu \mathrm{m}$ ). Zooplankton thus collected were subjected to close visual observation, under a binocular microscope to ensure the absence of any foreign particles and sorted. The composition of zooplankton samples from all the stations of both basins showed that copepods were the most dominant in all the samples. Chaetognaths were next in abundance, followed by ostracods and euphausids. Due to different potential for the accumulation of metals in copepods, ostracods, and euphausids, the sample was sorted and only mixed copepods (zooplankton) were used for the estimation of metals. The zooplankton samples (mixed copepods) were placed in a small nylon sieve and thoroughly rinsed with Milli-Q water to remove salts. Water adhering to the samples was removed by placing the sieve on high-quality filter paper, without any contamination. Subsequently, the samples were dried in an oven at $65^{\circ} \mathrm{C}$ and stored in a vacuum desiccator. Water samples were collected using a polyvinyl chloride-coated new stainless steel CTD-rosette sampler with precleaned, 5-L. Teflon-coated GoFlo bottles (General Oceanics). On recovery, samples were filtered directly from the Go-Flo samplers, under nitrogen pressure, through preweighed and acid-washed $0.45-\mu \mathrm{m}$ membrane (Millipore) filters mounted on Teflon filter blocks to separate them into dissolved and particulate fractions. The filtered water samples were stored after acidifying with pure $\mathrm{HCl}$ to $\mathrm{pH}$ 2-3.

Trace metals (Fe, $\mathrm{Co}, \mathrm{Ni}, \mathrm{Cu}, \mathrm{Zn}, \mathrm{Cd}$, and $\mathrm{Pb}$ ) in water, using ammonium pyrrolidine dithiocarbamate-methyl isobutyl ketone extraction (Brooks et al., 1967), were analyzed by Graphite Furnace Atomic Absorption Spectrophotometer (GFAAS, ZL4110). The procedure of dissolved metal was tested using the estuarine water reference material - St. Lawrence Estuarine Water (SLEW-2, $\mathrm{n}=5$ ) from the National Research Council of Canada (NRC) - to check the analytical quality.

Zooplankton samples were first powdered, and aliquots of approximately $300 \mathrm{mg}$ were digested for $3 \mathrm{~h}$ at $80^{\circ} \mathrm{C}$ with 300 $\mu \mathrm{L} \mathrm{HNO}_{3}(65 \%$, suprapure, Merck) in tightly closed 2-mL Eppendorf reaction tubes. The digests were made up to $25 \mathrm{~mL}$ with $\mathrm{HCl}(0.1 \mathrm{~N})$ and analyzed by a flame atomic absorption spectrophotometer (PE A Aanalyst100). The precision and accuracy of analysis was checked by replicate measurements $(\mathrm{n}=5)$ of target metals in a standard reference material of marine biota sample-Defated Lobster Tomalley (TORT-2, Lobster Hepatopancreas, National Research Council, Canada). The analyzed values obtained for the reference materials of seawater and biota are in excellent agreement with the certified values.

Bioaccumulation factors (concentration factors) were calculated for each metal and organism as the ratio of the metal concentration in the organism's body and its concentration in the ambient water. The bioaccumulation factors for zooplankton were based on dry weights and the same concentration units were used for seawater and zooplankton for its estimation. All metal concentration values in water samples are reported in ppb, whereas in zooplankton the values reported are in ppm dry weight.

\section{Results}

The concentrations of trace metals in the seawater and zooplankton from the coastal and offshore stations of the eastern Arabian Sea are presented in Tables 1-4. In the Arabian Sea, low trace metal concentrations were found in water and zooplankton from the open ocean stations, whereas coastal samples taken from off Goa (Station Positions: A13 and A14) showed higher concentrations followed by samples taken from off Kanyakumari (Station Positions: A1 and A2). 


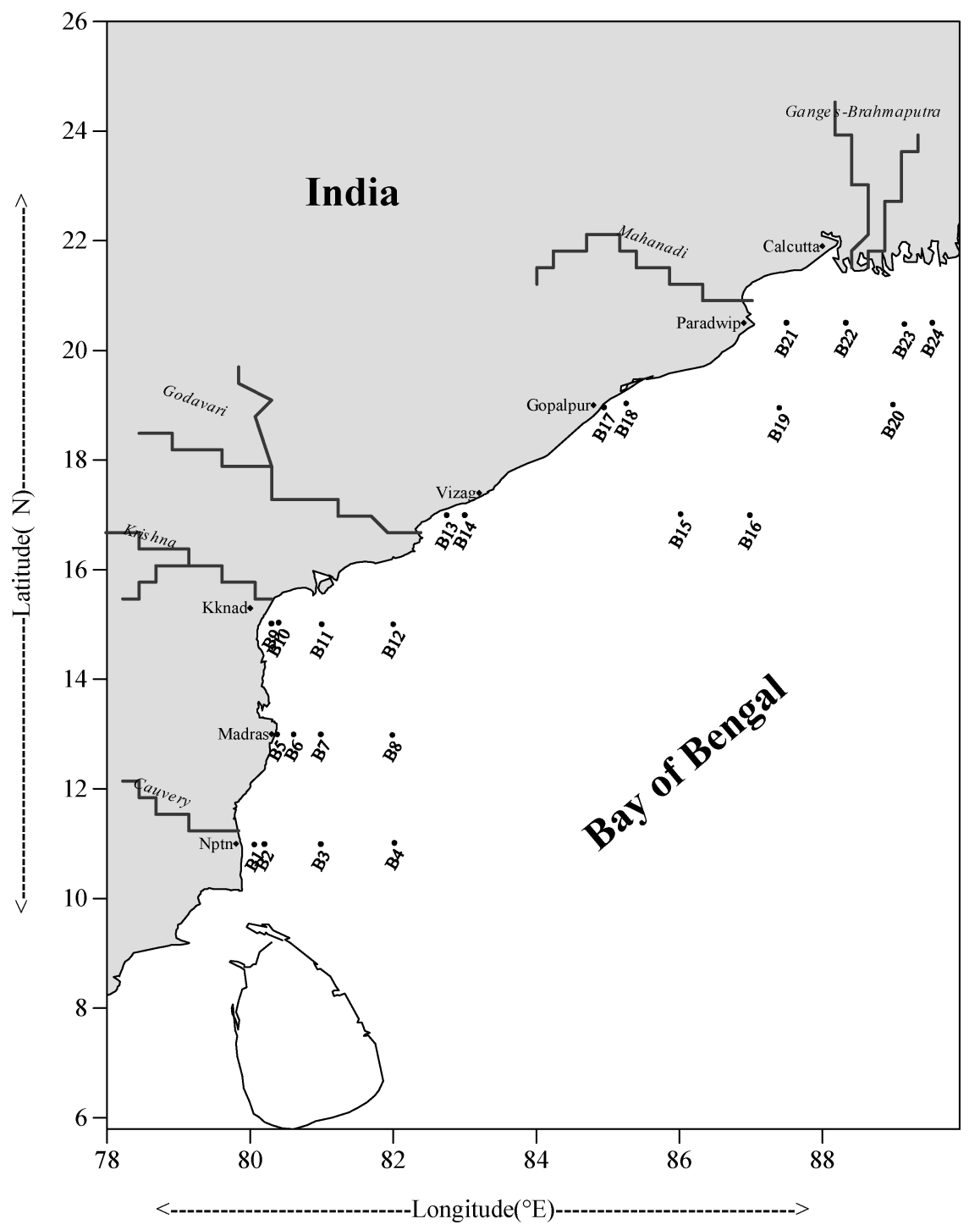

Figure 1. Map of the western Bay of Bengal with station locations.

The concentration of trace metals in the seawater and zooplankton from the coastal and offshore stations of the western Bay of Bengal are presented in Tables 5-8. In the Bay of Bengal, low trace metal concentrations were found in seawater and zooplankton from the coastal stations, except those samples from off Visakhapatnam (station positions: B13 and B14) and followed by off Madras transect (station positions: B5 and B6) where the levels were high. Further, an offshore enrichment of trace metals in zooplankton from the open ocean stations off Gopalpur (station position: B19), followed by open ocean stations off Visakhapatnam (station position: B16) and open ocean stations off Nagapattinam transect (station position: B4) where the levels were high. The concentrations of trace metals observed in zooplankton samples from the coastal and offshore samples of the Bay of Bengal and Arabian Sea might be due to their higher concentrations existing in the ambient medium.

The average $\mathrm{Fe}$ content $(50,980 \mathrm{ppm})$ in zooplankton and seawater (3.03 ppb) off Visakhapatnam coast showed a 9-fold and 4-fold increase in its concentration, respectively, compared with coastal stations off Nagapattinam transect in the Bay of Bengal. This might be due to extensive iron ore handling in the outer Visakhapatnam harbor, its gradual dissipation into the coastal regions, and surface runoff from the Godavari River. Relatively high concentration of FE (22864 ppm) in zooplankton and seawater (2.88 ppb), respectively, of coastal samples off Madras coast obtained in the present investigations compared to oceanic data also might be due to iron ore handling in the port and the subsequent input of this terrigenous material towards the coastal areas by land drainage and currents.

The average $\mathrm{Fe}$ content $(14,166 \mathrm{ppm})$ in zooplankton and seawater $(6.77 \mathrm{ppb})$ off Goa coast showed a 2-fold and 6fold increase in its concentration, respectively, when compared to coastal stations off Veraval in the Arabian Sea. Increased metal levels in water and zooplankton off Goa might be due to extensive iron ore handling in and around the Goa port and its subsequent dissipation into coastal regions by runoff from 
Table 1. Dissolved trace metals (ppb) from the coastal stations of the eastern Arabian Sea

\begin{tabular}{|c|c|c|c|c|c|c|c|}
\hline $\begin{array}{l}\text { Station } \\
\text { number }\end{array}$ & $\mathrm{Fe}(\mathrm{ppb})$ & $\mathrm{Co}(\mathrm{ppb})$ & $\mathrm{Ni}(\mathrm{ppb})$ & $\mathrm{Cu}(\mathrm{ppb})$ & $\mathrm{Zn}(\mathrm{ppb})$ & $\mathrm{Cd}(\mathrm{ppb})$ & $\mathrm{Pb}(\mathrm{ppb})$ \\
\hline A1 & 5.70 & 0.045 & 0.078 & 1.86 & 2.40 & 0.091 & 1.295 \\
\hline $\mathrm{A} 2$ & 5.70 & 0.044 & 0.077 & 1.86 & 2.40 & 0.089 & 1.295 \\
\hline A5 & 2.06 & 0.019 & 0.045 & 1.15 & 0.90 & 0.034 & 0.775 \\
\hline A6 & 2.33 & 0.038 & 0.048 & 1.14 & 0.80 & 0.048 & 0.690 \\
\hline A9 & 1.27 & 0.014 & 0.074 & 1.81 & 1.35 & 0.074 & 0.493 \\
\hline A10 & 1.96 & 0.024 & 0.029 & 1.43 & 1.09 & 0.029 & 1.133 \\
\hline A13 & 6.75 & 0.055 & 0.098 & 2.25 & 2.69 & 0.098 & 1.543 \\
\hline A14 & 6.79 & 0.054 & 0.097 & 2.26 & 2.61 & 0.099 & 1.543 \\
\hline A17 & 1.49 & 0.013 & 0.078 & 1.11 & 1.57 & 0.076 & 0.328 \\
\hline A18 & 5.41 & 0.011 & 0.028 & 0.95 & 0.84 & 0.059 & 1.010 \\
\hline A21 & 3.22 & 0.014 & 0.032 & 0.86 & 1.21 & 0.064 & 0.548 \\
\hline A22 & 1.42 & 0.010 & 0.024 & 0.99 & 1.70 & 0.068 & 0.453 \\
\hline A25 & 0.98 & 0.012 & 0.038 & 0.23 & 1.18 & 0.076 & 0.240 \\
\hline A26 & 1.05 & 0.018 & 0.039 & 0.21 & 1.90 & 0.039 & 0.228 \\
\hline
\end{tabular}

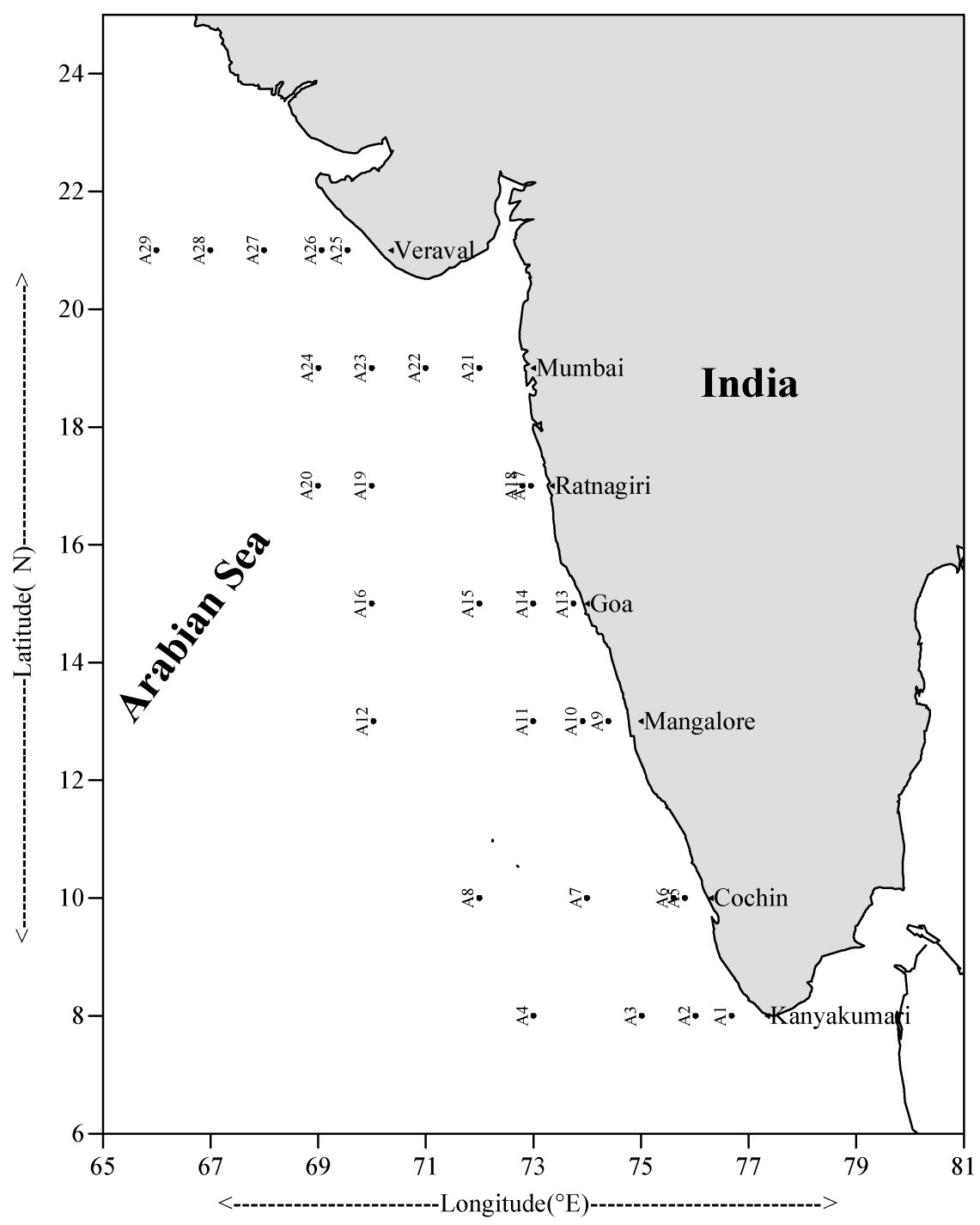

Figure 2. Map of the eastern Arabian Sea with station locations. 
Table 2. Dissolved trace metals ( $p p b$ ) from the offshore stations of the eastern Arabian Sea

\begin{tabular}{lccccccc}
\hline $\begin{array}{l}\text { Station } \\
\text { number }\end{array}$ & $\mathrm{Fe}(\mathrm{ppb})$ & $\mathrm{Co}(\mathrm{ppb})$ & $\mathrm{Ni}(\mathrm{ppb})$ & $\mathrm{Cu}(\mathrm{ppb})$ & $\mathrm{Zn}(\mathrm{ppb})$ & $\mathrm{Cd}(\mathrm{ppb})$ & $\mathrm{Pb}(\mathrm{ppb})$ \\
\hline $\mathrm{A} 3$ & 3.05 & 0.031 & 0.031 & 1.33 & 0.56 & 0.066 & 1.043 \\
$\mathrm{~A} 4$ & 1.78 & 0.031 & 0.041 & 0.69 & 1.33 & 0.081 & 0.588 \\
$\mathrm{~A} 7$ & 2.29 & 0.037 & 0.058 & 0.81 & 1.01 & 0.082 & 0.705 \\
$\mathrm{~A} 8$ & 1.88 & 0.036 & 0.035 & 1.51 & 1.44 & 0.051 & 0.603 \\
$\mathrm{~A} 11$ & 2.91 & 0.014 & 0.035 & 1.63 & 1.31 & 0.074 & 0.710 \\
$\mathrm{~A} 12$ & 3.07 & 0.014 & 0.035 & 1.63 & 1.31 & 0.074 & 0.710 \\
$\mathrm{~A} 15$ & 1.74 & 0.013 & 0.025 & 1.06 & 0.86 & 0.058 & 1.000 \\
$\mathrm{~A} 16$ & 2.75 & 0.015 & 0.035 & 0.62 & 1.95 & 0.066 & 0.498 \\
$\mathrm{~A} 19$ & 1.10 & 0.025 & 0.055 & 1.54 & 1.09 & 0.058 & 0.873 \\
$\mathrm{~A} 20$ & 1.10 & 0.025 & 0.055 & 1.54 & 1.09 & 0.058 & 0.548 \\
$\mathrm{~A} 23$ & 1.48 & 0.012 & 0.061 & 0.99 & 1.89 & 0.074 & 0.455 \\
$\mathrm{~A} 24$ & 1.48 & 0.012 & 0.061 & 0.99 & 1.89 & 0.074 & 0.455 \\
$\mathrm{~A} 27$ & 1.53 & 0.010 & 0.032 & 0.12 & 0.39 & 0.060 & 0.640 \\
$\mathrm{~A} 28$ & 1.53 & 0.010 & 0.032 & 0.12 & 0.39 & 0.060 & 0.640 \\
$\mathrm{~A} 29$ & 1.33 & 0.012 & 0.038 & 0.96 & 0.98 & 0.056 & 0.260 \\
\hline
\end{tabular}

Table 3. Zooplankton trace metals (ppm) from the coastal stations of the eastern Arabian Sea

\begin{tabular}{|c|c|c|c|c|c|c|c|}
\hline $\begin{array}{l}\text { Station } \\
\text { number }\end{array}$ & $\mathrm{Fe}(\mathrm{ppm})$ & Co (ppm) & $\mathrm{Ni}$ (ppm) & $\mathrm{Cu}(\mathrm{ppm})$ & $\mathrm{Zn}(\mathrm{ppm})$ & $\mathrm{Cd}$ (ppm) & $\mathrm{Pb}(\mathrm{ppm})$ \\
\hline A1 & 8900.0 & 33.4 & 47.6 & 44.0 & 1583.0 & 25.7 & 13.7 \\
\hline A2 & 9777.5 & 36.5 & 45.2 & 43.9 & 1601.6 & 24.4 & 15.0 \\
\hline A5 & 1111.0 & 9.1 & 7.6 & 5.2 & 81.3 & 22.6 & 0.9 \\
\hline A6 & 833.2 & 30.4 & 7.6 & 3.4 & 183.0 & 19.9 & 2.7 \\
\hline A9 & 1319.3 & 6.1 & 12.6 & 6.9 & 122.0 & 19.3 & 1.5 \\
\hline A10 & 2291.4 & 6.1 & 17.7 & 5.2 & 284.7 & 19.3 & 1.6 \\
\hline A13 & $13,749.6$ & 41.0 & 65.2 & 65.5 & 1891.2 & 28.6 & 23.3 \\
\hline A14 & $14,583.0$ & 38.4 & 62.2 & 63.9 & 1799.9 & 29.7 & 22.5 \\
\hline A17 & 1111.0 & 6.1 & 20.2 & 37.8 & 315.2 & 11.2 & 7.1 \\
\hline A18 & 4305.1 & 9.1 & 25.3 & 20.6 & 447.3 & 8.7 & 3.0 \\
\hline A21 & 5068.9 & 6.1 & 12.6 & 18.9 & 406.7 & 7.5 & 4.5 \\
\hline A22 & 1180.4 & 9.1 & 20.2 & 3.4 & 213.5 & 4.4 & 2.7 \\
\hline A 25 & 8888.1 & 15.2 & 22.7 & 6.9 & 223.7 & 9.9 & 0.2 \\
\hline A26 & 1249.9 & 6.1 & 12.6 & 32.9 & 294.9 & 11.8 & 5.3 \\
\hline
\end{tabular}

Table 4. Zooplankton trace metals (ppm) from the offshore stations of the eastern Arabian Sea

\begin{tabular}{lccccccc}
\hline $\begin{array}{l}\text { Station } \\
\text { number }\end{array}$ & $\mathrm{Fe}(\mathrm{ppm})$ & $\mathrm{Co}(\mathrm{ppm})$ & $\mathrm{Ni}(\mathrm{ppm})$ & $\mathrm{Cu}(\mathrm{ppm})$ & $\mathrm{Zn}(\mathrm{ppm})$ & $\mathrm{Cd}(\mathrm{ppm})$ & $\mathrm{Pb}(\mathrm{ppm})$ \\
\hline $\mathrm{A} 3$ & 763.8 & 8.9 & 7.6 & 5.2 & 132.2 & 14.9 & 1.5 \\
$\mathrm{~A} 4$ & 556.0 & 8.9 & 12.6 & 12.0 & 91.5 & 20.5 & 1.0 \\
$\mathrm{~A} 7$ & 278.0 & 30.4 & 15.2 & 3.4 & 61.1 & 14.9 & 1.1 \\
A8 & 1041.5 & 9.1 & 12.6 & 18.9 & 132.1 & 23.6 & 5.2 \\
$\mathrm{~A} 11$ & 763.8 & 6.1 & 7.6 & 13.8 & 132.2 & 22.4 & 1.1 \\
$\mathrm{~A} 12$ & 486.1 & 15.2 & 12.6 & 22.3 & 101.7 & 13.7 & 0.8 \\
$\mathrm{~A} 15$ & 3124.0 & 6.1 & 12.6 & 25.8 & 376.2 & 21.2 & 4.1 \\
$\mathrm{~A} 16$ & 1180.4 & 12.2 & 20.2 & 30.9 & 132.2 & 22.6 & 1.3 \\
$\mathrm{~A} 19$ & 4027.4 & 12.2 & 22.7 & 25.8 & 203.3 & 14.9 & 0.6 \\
$\mathrm{~A} 20$ & 4027.4 & 12.2 & 22.7 & 25.8 & 203.3 & 14.9 & 0.6 \\
$\mathrm{~A} 23$ & 1041.6 & 6.1 & 12.6 & 8.6 & 162.6 & 6.8 & 1.9 \\
$\mathrm{~A} 24$ & 2222.0 & 6.1 & 20.2 & 17.2 & 650.7 & 11.2 & 2.4 \\
$\mathrm{~A} 27$ & 2291.4 & 6.1 & 12.6 & 20.6 & 213.5 & 11.2 & 1.7 \\
A28 & 3540.0 & 15.2 & 13.3 & 28.6 & 698.0 & 8.1 & 12.7 \\
A29 & 833.2 & 6.1 & 15.2 & 5.2 & 111.8 & 13.7 & 1.4 \\
\hline
\end{tabular}


Table 5. Dissolved trace metals (ppb) from the coastal stations of the western Bay of Bengal

\begin{tabular}{lccccccc}
\hline $\begin{array}{l}\text { Station } \\
\text { number }\end{array}$ & $\mathrm{Fe}(\mathrm{ppb})$ & $\mathrm{Co}(\mathrm{ppb})$ & $\mathrm{Ni}(\mathrm{ppb})$ & $\mathrm{Cu}(\mathrm{ppb})$ & $\mathrm{Zn}(\mathrm{ppb})$ & $\mathrm{Cd}(\mathrm{ppb})$ & $\mathrm{Pb}(\mathrm{ppb})$ \\
\hline B1 & 0.78 & 0.091 & 0.021 & 0.44 & 1.28 & 0.012 & 0.113 \\
B2 & 0.88 & 0.051 & 0.021 & 0.69 & 1.74 & 0.012 & 0.108 \\
B5 & 2.87 & 0.120 & 0.081 & 1.27 & 2.31 & 0.041 & 0.511 \\
B6 & 2.89 & 0.122 & 0.080 & 1.29 & 2.40 & 0.039 & 0.521 \\
B9 & 2.28 & 0.030 & 0.018 & 0.58 & 1.05 & 0.018 & 0.230 \\
B10 & 2.51 & 0.050 & 0.031 & 0.62 & 1.80 & 0.012 & 0.341 \\
B13 & 3.02 & 0.151 & 0.098 & 1.80 & 2.79 & 0.048 & 0.685 \\
B14 & 3.04 & 0.148 & 0.096 & 1.98 & 2.84 & 0.046 & 0.700 \\
B17 & 2.80 & 0.043 & 0.023 & 1.69 & 0.98 & 0.044 & 0.305 \\
B18 & 2.23 & 0.015 & 0.022 & 1.08 & 0.92 & 0.033 & 0.395 \\
B21 & 2.66 & 0.033 & 0.020 & 1.07 & 1.72 & 0.020 & 0.283 \\
B22 & 2.64 & 0.04 & 0.021 & 0.62 & 0.98 & 0.033 & 0.273 \\
\hline
\end{tabular}

Table 6. Dissolved trace metals (ppb) from the offshore stations of the western Bay of Bengal

\begin{tabular}{lccccccc}
\hline $\begin{array}{l}\text { Station } \\
\text { number }\end{array}$ & $\mathrm{Fe}(\mathrm{ppb})$ & $\mathrm{Co}(\mathrm{ppb})$ & $\mathrm{Ni}(\mathrm{ppb})$ & $\mathrm{Cu}(\mathrm{ppb})$ & $\mathrm{Zn}(\mathrm{ppb})$ & $\mathrm{Cd}(\mathrm{ppb})$ & $\mathrm{Pb}(\mathrm{ppb})$ \\
\hline B3 & 2.21 & 0.102 & 0.071 & 0.22 & 0.98 & 0.015 & 0.115 \\
$\mathrm{~B} 4$ & 2.81 & 0.121 & 0.035 & 0.58 & 0.98 & 0.021 & 0.143 \\
B7 & 1.21 & 0.108 & 0.034 & 0.62 & 0.78 & 0.017 & 0.491 \\
B8 & 2.02 & 0.112 & 0.021 & 0.56 & 0.78 & 0.018 & 0.156 \\
B11 & 2.59 & 0.084 & 0.023 & 0.65 & 0.98 & 0.018 & 0.385 \\
B12 & 1.29 & 0.078 & 0.062 & 0.52 & 0.98 & 0.021 & 0.113 \\
B15 & 2.51 & 0.12 & 0.061 & 0.89 & 0.98 & 0.021 & 0.348 \\
B16 & 2.37 & 0.110 & 0.081 & 1.61 & 1.88 & 0.035 & 0.170 \\
B19 & 2.72 & 0.008 & 0.032 & 1.03 & 0.98 & 0.034 & 0.188 \\
B20 & 2.70 & 0.008 & 0.032 & 0.59 & 0.95 & 0.021 & 0.488 \\
B23 & 2.51 & 0.045 & 0.060 & 0.54 & 0.98 & 0.019 & 0.145 \\
B24 & 2.51 & 0.045 & 0.060 & 0.54 & 0.98 & 0.019 & 0.145 \\
\hline
\end{tabular}

Table 7. Zooplankton trace metals (ppm) from the coastal stations of the western Bay of Bengal

\begin{tabular}{lrcccrrr}
\hline $\begin{array}{l}\text { Station } \\
\text { number }\end{array}$ & $\mathrm{Fe}(\mathrm{ppm})$ & $\mathrm{Co}(\mathrm{ppm})$ & $\mathrm{Ni}(\mathrm{ppm})$ & $\mathrm{Cu}(\mathrm{ppm})$ & $\mathrm{Zn}(\mathrm{ppm})$ & $\mathrm{Cd}(\mathrm{ppm})$ & $\mathrm{Pb}(\mathrm{ppm})$ \\
\hline B1 & 5625.1 & 20.0 & 15.0 & 45.1 & 358.1 & 12.2 & 1.8 \\
B2 & 5569.2 & 26.1 & 18.2 & 56.2 & 1033.2 & 12.3 & 4.4 \\
B5 & $23,437.1$ & 24.2 & 45.1 & 75.3 & 5000.3 & 28.1 & 16.0 \\
B6 & $22,291.3$ & 40.3 & 43.1 & 73.1 & 4889.4 & 30.2 & 12.0 \\
B9 & 1968.1 & 14.1 & 18.1 & 19.2 & 205.0 & 8.2 & 1.4 \\
B10 & 1350.2 & 14.2 & 21.0 & 22.2 & 241.1 & 13.3 & 1.8 \\
B13 & $50,999.3$ & 46.0 & 52.1 & 79.0 & 7162.2 & 42.3 & 21.1 \\
B14 & $50,962.1$ & 36.0 & 46.1 & 78.1 & 7066.1 & 41.4 & 20.1 \\
B17 & $14,200.3$ & 18.1 & 21.1 & 42.2 & 1400.2 & 11.2 & 4.9 \\
B18 & $13,950.4$ & 17.2 & 23.0 & 40.1 & 1383.3 & 10.1 & 5.6 \\
B21 & 3125.1 & 18.3 & 21.1 & 23.3 & 179.3 & 12.2 & 2.1 \\
B22 & 2925.1 & 17.1 & 18.1 & 21.0 & 174.1 & 10.2 & 1.9 \\
\hline
\end{tabular}

the Mandovi and Zuari estuaries. The observed high average concentration of $\mathrm{Fe}$ in zooplankton $(9338 \mathrm{ppm})$ and seawater $(5.70 \mathrm{ppb})$ off Kanyakumari coast during inter-monsoon fall might be related to surface runoff from Kerala Coast rivers and upwelling in the area.
The average Co content in seawater and zooplankton of the coastal stations off Visakhapatnam (0.149 ppb and $41 \mathrm{ppm})$ and off Madras ( $0.121 \mathrm{ppb}$ and $38 \mathrm{ppm}$ ) showed higher values than the other coastal stations in the Bay of Bengal. Similarly, in the Arabian Sea, the average Co in seawater and zooplankton of 
Table 8. Zooplankton trace metals (ppm) from the offshore stations of the western Bay of Bengal

\begin{tabular}{lrcrrrrr}
\hline $\begin{array}{l}\text { Station } \\
\text { number }\end{array}$ & $\mathrm{Fe}(\mathrm{ppm})$ & $\mathrm{Co}(\mathrm{ppm})$ & $\mathrm{Ni}(\mathrm{ppm})$ & $\mathrm{Cu}(\mathrm{ppm})$ & $\mathrm{Zn}(\mathrm{ppm})$ & $\mathrm{Cd}(\mathrm{ppm})$ & $\mathrm{Pb}(\mathrm{ppm})$ \\
\hline B3 & 1125.2 & 17.2 & 20.1 & 24.2 & 425.0 & 11.0 & 2.2 \\
B4 & $14,062.3$ & 24.3 & 38.4 & 62.3 & 3337.1 & 25.1 & 4.9 \\
B7 & 4275.3 & 20.4 & 20.3 & 35.3 & 484.2 & 12.2 & 1.9 \\
B8 & 3543.4 & 14.1 & 15.1 & 30.1 & 392.3 & 9.3 & 1.6 \\
B11 & 4106.1 & 22.1 & 30.2 & 27.2 & 375.4 & 15.1 & 1.5 \\
B12 & 5625.2 & 25.2 & 51.3 & 32.1 & 783.3 & 34.2 & 3.5 \\
B15 & 4556.2 & 17.3 & 15.1 & 34.0 & 458.2 & 11.2 & 7.7 \\
B16 & $26,212.3$ & 38.2 & 38.1 & 69.0 & 1458.1 & 18.3 & 16.2 \\
B19 & $41,512.3$ & 34.1 & 48.2 & 74.2 & 4233.0 & 26.3 & 15.9 \\
B20 & $15,075.3$ & 20.1 & 33.3 & 71.3 & 1650.1 & 9.2 & 3.1 \\
B23 & $10,631.3$ & 21.2 & 30.3 & 39.0 & 2666.2 & 25.3 & 2.8 \\
B24 & $10,631.2$ & 21.2 & 30.3 & 39.0 & 2666.2 & 24.0 & 2.8 \\
\hline
\end{tabular}

the coastal stations off Goa ( $0.055 \mathrm{ppb}$ and $39.7 \mathrm{ppm})$ and off Kanyakumari ( $0.044 \mathrm{ppb}$ and $34.95 \mathrm{ppm}$ ) showed higher values than the other coastal stations in the Arabian Sea. This might be due to land drainage in these coastal stations of the Arabian Sea and Bay of Bengal.

It was evident from the data of the Bay of Bengal that coastal stations off Visakhapatnam transect recorded higher average values for $\mathrm{Ni}$ in seawater and zooplankton $(0.097 \mathrm{ppb}$ and $49 \mathrm{ppm})$ followed by off Madras transect ( $0.08 \mathrm{ppb}$ and $44 \mathrm{ppm})$. Similarly, from the data of the Arabian Sea that coastal stations off Goa transect recorded higher average values for $\mathrm{Ni}$ in seawater and zooplankton $(0.098 \mathrm{ppb}$ and $64 \mathrm{ppm})$ followed by off Kanyakumari transect ( $0.077 \mathrm{ppb}$ and $46.6 \mathrm{ppm}$ ). Higher concentration at the Visakhapatnam transect may be due to discharge of industrial effluents and domestic sewage and its gradual dispersion towards the nearby coastal region, together with surface runoff from Godavari rivers. Relatively higher concentration of $\mathrm{Ni}$ in coastal zooplankton samples off Madras coast might be due to land drainage. The observed relatively higher concentrations of $\mathrm{Ni}$ in zooplankton from off Goa transect might be related to ore-bearing landmass of the area, whereas the high concentration observed off Kanyakumari transect is related to upwelling and river runoff from the Kerala coast.

The coastal stations off Visakhapatnam in the Bay of Bengal had higher average values for $\mathrm{Cu}$ in water and zooplankton (1.89 ppb and $78 \mathrm{ppm})$ followed by Madras transect (1.28 $\mathrm{ppb}$ and $74 \mathrm{ppm}$ ). Also, the coastal stations off Goa had higher average values for $\mathrm{Cu}$ in water and zooplankton $(2.25 \mathrm{ppb}$ and $64 \mathrm{ppm}$ ) followed by Kanyakumari transect (1.86 ppb and $44 \mathrm{ppm})$ in the Arabian Sea. The observed high concentrations in Visakhapatnam transect can be attributed to pollution in Visakhapatnam harbor by industrial effluents and domestic sewage. Another possibility for higher concentration of $\mathrm{Cu}$ in zooplankton of the coastal stations off Visakhapatnam might be the flooding and subsequent leaching of $\mathrm{Cu}$ by land drainage to the Godavari River due to heavy rainfall of the period. The high concentrations of $\mathrm{Cu}$ in zooplankton samples off Goa and off Kanyakumari transect might be related to surface runoff in these coastal areas during inter-monsoon fall. Moreover, in the presence of high organic matter, $\mathrm{Cu}$ forms soluble and chelating of insoluble metal also favors higher concentration in the coastal and offshore zooplankton samples of both the Arabian Sea and Bay of Bengal (Raman and Ganapati, 1983).

Average concentration of $\mathrm{Zn}$ in seawater and zooplankton of the coastal stations off Visakhapatnam (2.82 ppb and $7114 \mathrm{ppm}$ ) and off Madras (2.36 ppb and $4944 \mathrm{ppm}$ ) were higher than that of the other coastal stations of the Bay of Bengal. Similarly, average concentration of $\mathrm{Zn}$ in seawater and zooplankton of the coastal stations off Goa (2.65 ppb and $1845 \mathrm{ppm})$ and off Kanyakumari (2.40 ppb and $1592 \mathrm{ppm}$ ) were also higher than that of the other coastal stations. The high concentration of $\mathrm{Zn}$ observed in seawater and zooplankton samples of the coastal stations of Visakhapatnam transect may be due to the drainage of domestic sewage, Godavari River waters, and industrial effluents into the inner harbor and their dissipation into the coastal regions. The effluents from the $\mathrm{Zn}$ smelter may also find their way into the coastal region through the Visakhapatnam harbor. This is further supported by high concentrations of Zn (276$480 \mathrm{ppm}$ ) in the effluents of Hindustan Zinc Ltd (Someswara Rao and Venkateswara Rao, 1989). However, the high concentrations observed in the coastal stations off Madras could be the result of land runoff from the port areas. The high concentration of $\mathrm{Zn}$ observed in seawater and zooplankton samples from off Goa coastal stations is related to the ore-bearing landmass of the area and associated land drainage in the coastal areas, whereas the high concentration of $\mathrm{Zn}$ observed in off Kanyakumari transect is associated with surface and riverine runoff of industrial effluents from the Kerala coast.

Average $\mathrm{Cd}$ values in seawater and in surface zooplankton of the coastal stations off Visakhapatnam (0.047 ppb and $41 \mathrm{ppm})$ and off Madras (0.041 ppb and $29 \mathrm{ppm})$ showed higher values than offshore samples in the respective transects of the Bay of Bengal. Similarly, in the Arabian Sea, average Cd values in seawater and in surface zooplankton of the coastal stations off Goa (0.098 ppb and 29 ppm) and off Kanyakumari (0.091 ppb and $25 \mathrm{ppm}$ ) showed higher values than offshore samples in the respective transects of the Arabian Sea. The high value off Visakhapatnam may be due to industrial effluents from $\mathrm{Zn}$ smelter into the harbor and its passage to the coastal areas, together with surface runoff from Godavari rivers and the high 
value in coastal area off Madras transect might be attributed to land drainage. The high value observed during inter-monsoon fall off Goa may be due to the rich ore-bearing landmass of the area and the associated surface runoff to the coastal areas, and the high value in coastal area off Kanyakumari transect might be attributed to surface runoff from the Kerala coast to adjacent coastal areas together with upwelling.

In the Bay of Bengal, a high average concentration of $\mathrm{Pb}$ $(20 \mathrm{ppm})$ in coastal zooplankton and seawater (0.69 ppb) samples off Visakhapatnam was observed and the same trend was observed in stations off Madras for zooplankton (14 ppm) and seawater $(0.516 \mathrm{ppb})$. In the Arabian Sea during inter-monsoon fall, a high average concentration of $\mathrm{Pb}(22 \mathrm{ppm})$ in coastal zooplankton and water (1.54 ppb) samples off Goa were found, followed by off Kanyakumari area for zooplankton (14 ppm) and seawater (1.3 ppb). The observed high metal levels in seawater and zooplankton in the Bay of Bengal might be attributed to high influxes of $\mathrm{Pb}$ in the Visakhapatnam and Madras regions, primarily from automotive exhausts or due to loading and unloading of large quantities of general and bulk cargo at these localities. The $\mathrm{Pb}$ is transported principally through the atmosphere and accommodated in the seawater following wet and dry deposition. The subsequent uptake of the metal by the zooplankton is evidenced by its high concentration within these whole bodies. $\mathrm{Pb}$ is known to form colloids in seawater, and such colloids would have adsorbed onto planktonic debris, which consequently might have resulted in higher concentration of this element in zooplankton from the coastal waters off Goa and off Kanyakumari during inter-monsoon fall.

\section{Discussion}

From the data it is clear that trace metal concentration in zooplankton can lead to identification of "hot spots." The spatial variation in the metal content was evident in the eastern Arabian Sea and western Bay of Bengal from the extensive area investigated. In general, coastal zooplankton samples showed higher values for all the metals than offshore samples in both the Arabian Sea and Bay of Bengal. Zooplankton in coastal areas versus open ocean have higher concentration of trace metals because of the influence of local sources such as river runoff, sewage discharge, industrial effluents, and also from enriched bottom waters. Port activities such as shipping, loading of Fe-Mn ore, and unloading of $\mathrm{Zn}-\mathrm{Pb}$ ore concentrates and other bulk cargo also partly contribute to the enhanced levels of some of these trace metals in seawater and zooplankton of the coastal areas of both the Arabian Sea and Bay of Bengal. Moreover, a large quantity of sediments impregnated with heavy metals are supplied by major rivers along the east coast and were constantly moved by waves either towards north or south depending on the direction and angle of wave approach with respect to the coast (Rengasamy and Jing, 2005). The offshore enrichment of trace metals in zooplankton from the open ocean stations off Gopalpur (station position: B19), followed by open ocean stations off Visakhapatnam (station position: B16) and open ocean
Table 9. Average concentration of trace metals in different compartments and average bioaccumulation (baf) factors for trace metals in zooplankton from the eastern Arabian Sea during inter-monsoon fall

\begin{tabular}{|c|c|c|c|c|c|c|c|}
\hline Metal & $\mathrm{Fe}$ & Co & $\mathrm{Ni}$ & $\mathrm{Cu}$ & $\mathrm{Zn}$ & $\mathrm{Cd}$ & $\mathrm{Pb}$ \\
\hline Dissolved (ppb) & 2.59 & 0.023 & 0.048 & 1.16 & 1.38 & 0.067 & 0.734 \\
\hline $\begin{array}{l}\text { Zooplankton } \\
\text { (ppm) }\end{array}$ & 1786.1 & 14.2 & 18.6 & 21.5 & 374.1 & 16.5 & 4.0 \\
\hline $\begin{array}{l}\text { Bioaccumulation } \\
\text { factors (baf) }\end{array}$ & $888,85^{\circ}$ & 629,36 & 402,16 & 34,02 & 294,1 & 265,74 & 5663 \\
\hline
\end{tabular}

stations off Nagapattinam transect (station position: B4), seems to be related to the southerly flowing East India coastal current from the head of the Bay of Bengal and the peculiar gyral circulation of the Bay of Bengal (Shetye et al., 1996). Under the influence of these gyres and as a consequence of the geometry of the east coast of India (U-shaped basin), the low-saline waters, probably of riverine origin, drift offshore by the simultaneous prevalence of anticlockwise surface currents, thereby favoring significant accumulation of trace metals in zooplankton. The slight increase of metals in water and zooplankton towards northern latitudes can be indicative of slight riverine influences in the metal concentrations. In winter, this southward-flowing East India coastal current carries warm and low-salinity waters from the northern Bay of Bengal (probably carrying riverine waters originating from Ganges-Brahmaputra, Godavari, Krishna, and Cauveri rivers) to the southern part of the peninsular India and feeds the northward-flowing West India coastal current in the Arabian Sea. The intrusion of this Bay of Bengal water into the Arabian Sea during winter monsoon and associated chemical and biological response have been reported (Prasanna Kumar et al., 2004).

The state of Goa is well known for its mining activities and major contribution to the economy from the export of more than 10 million tons per year of Fe-Mn ore (Parulekar et al., 1986). The availability of trace metals in the surrounding environment and their accumulation to aquatic organisms such as zooplankton are therefore obvious and can be correlated with the mineral deposits in the adjacent areas. The present investigation therefore provides important information on the leaching of metals from the mining field and its subsequent accumulation in marine zooplankton. Thus, in the Arabian Sea during inter-monsoon fall, the enrichment of trace metals in water and zooplankton from the coastal samples off Goa is possibly related to the orebearing landmass and associated surface runoff from the near by Mandovi and Zuari estuaries to the coastal waters off the Goa transect (George, 1984; Sundar and Shetye, 2005; Shankar et al., 2004). However, the similar enrichment of trace metals in water and zooplankton at the coastal waters off Kanyakumari transect is coupled with the upwelling of metal rich subsurface waters and surface runoff from the Kerala Coast rivers (Muraleedharan et al., 1995; Rejomon, 2005). These factors in turn lead to enrichment of metals in zooplankton from the coastal waters of the southwest coast of India. 
The average concentration of trace metals in zooplankton from the Arabian Sea (Table 9) followed this order: $\mathrm{Fe}>\mathrm{Zn}>$ $\mathrm{Cu}>\mathrm{Ni}>\mathrm{Cd}>\mathrm{Co}>\mathrm{Pb}$, whereas concentrations from the Bay of Bengal (Table 10) followed this order: $\mathrm{Fe}>\mathrm{Zn}>\mathrm{Cu}>$ $\mathrm{Ni}>\mathrm{Co}>\mathrm{Cd}>\mathrm{Pb}$. The sequence of metal levels in zooplankton from both the Arabian Sea and Bay of Bengal followed the same order for $\mathrm{Fe}, \mathrm{Zn}, \mathrm{Cu}, \mathrm{Ni}$, and $\mathrm{Pb}$ but not for $\mathrm{Cd}$ and $\mathrm{Co}$. All the elements showed relative enrichment in zooplankton from the Bay of Bengal rather than from the Arabian Sea. The element Fe showed an 8-fold increase in its concentration from the Bay of Bengal compared with the concentration of $\mathrm{Fe}$ in zooplankton from the Arabian Sea. Zn also showed a 5-fold increase in its concentration from the Bay of Bengal compared with the concentration of $\mathrm{Zn}$ in zooplankton from the Arabian Sea. The element $\mathrm{Cu}$ in zooplankton showed a 2-fold increase in its concentration from the Bay of Bengal compared with the concentration of $\mathrm{Cu}$ in zooplankton from the Arabian Sea. Similarly, the elements $\mathrm{Co}, \mathrm{Ni}, \mathrm{Cd}$, and $\mathrm{Pb}$ were slightly enriched (1.131.70 times) in zooplankton from the Bay of Bengal compared with zooplankton samples taken from the Arabian Sea.

Because bioaccumulation factors represent the potential of organisms to bioaccumulate metals, a comparative ranking of bioaccumulation factors is of great interest. The bioaccumulation factor is evaluated in relation to the concentration of the soluble metal ion in which the zooplankton inhabits. The average bioaccumulation factor of elements in zooplankton from the Arabian Sea (Table 9) followed this order: $\mathrm{Fe}>\mathrm{Co}>\mathrm{Ni}>\mathrm{Zn}>$ $\mathrm{Cd}>\mathrm{Cu}>\mathrm{Pb}$, whereas the average bioaccumulation factor of elements in zooplankton from the Bay of Bengal (Table 10) followed this order: $\mathrm{Fe}>\mathrm{Zn}>\mathrm{Cd}>\mathrm{Ni}>\mathrm{Co}>\mathrm{Cu}>\mathrm{Pb}$. The sequence of bioaccumulation factors for all elements except $\mathrm{Fe}$, $\mathrm{Cu}$, and $\mathrm{Pb}$ varied for both the Arabian Sea and Bay of Bengal zooplankton. The bioaccumulation factor for Fe and $\mathrm{Zn}$ in zooplankton from the Bay of Bengal showed concentrations 6- and 5-fold higher than the Arabian Sea zooplankton although both areas had same range of dissolved Fe and zinc. Similarly, the bioaccumulation factor for $\mathrm{Pb}$ in zooplankton from the Bay of Bengal showed concentrations 4-fold higher than in the Arabian Sea zooplankton although the concentration of dissolved $\mathrm{Pb}$ is 2.4 times lower than in the Arabian Sea. The bioaccumulation factor for $\mathrm{Cd}$ in the Bay of Bengal zooplankton showed concentrations 3-fold higher than Arabian Sea zooplankton although the concentration of dissolved Cd was 2.5 times lower than in the Arabian Sea. Moreover, the bioaccumulation factor for $\mathrm{Ni}$ and $\mathrm{Cu}$ in zooplankton from the Bay of Bengal showed that it

Table 10. Average concentration of trace metals in different compartments and average bioaccumulation (baf) factors for trace metals in zooplankton from the western Bay of Bengal during winter monsoon

\begin{tabular}{|c|c|c|c|c|c|c|c|}
\hline Metal & $\mathrm{Fe}$ & $\mathrm{Co}$ & $\mathrm{Ni}$ & $\mathrm{Cu}$ & $\mathrm{Zn}$ & $\mathrm{Cd}$ & $\mathrm{Pb}$ \\
\hline Dissolved (ppb) & 2.34 & 0.076 & 0.046 & 0.895 & 1.38 & 0.026 & 0.306 \\
\hline $\begin{array}{l}\text { Zooplankton } \\
\text { (ppm) }\end{array}$ & $14,073.1$ & 24.2 & 29.5 & 46.2 & 2000.1 & 18.7 & 6.55 \\
\hline \multicolumn{8}{|c|}{$\begin{array}{l}\text { Bioaccumulation 5,709,092 614,013 760,852 58,943 1,356,670 775,167 23,966 } \\
\text { factors (baf) }\end{array}$} \\
\hline
\end{tabular}

was 1.7 times higher than the Arabian Sea zooplankton although the concentration of dissolved Ni remained in the same range in both areas and the concentration of dissolved $\mathrm{Cu}$ was 1.3 times lower than that of the Arabian Sea. However, the bioaccumulation factor of Co in zooplankton did not change appreciably in both areas, although the concentration of dissolved Co in Arabian Sea was 3.3 times lower than that in the Bay of Bengal.

Further, comparison of the bioaccumulation factor for $\mathrm{Fe}$ in zooplankton from the Bay of Bengal and Arabian Sea showed that the bay concentration is 8-fold that of the sea. Similarly, for these water bodies, comparison of the bioaccumulation factor for $\mathrm{Zn}$ in zooplankton showed that the bay concentration is 5-fold that of the sea, although both areas have almost the same range of dissolved Fe and $\mathrm{Zn}$ concentrations. Also, a comparison of bioaccumulation factor for Fe and Co during the present study in Bay of Bengal zooplankton with the report mentioned previously was 2.7 and 3.2 times lower, respectively. The 8-fold and 5-fold enrichment of $\mathrm{Fe}$ and $\mathrm{Zn}$ concentrations in zooplankton from the Bay of Bengal compared with the Arabian Sea zooplankton might be due to high bioaccumulation factor rather than a higher degree of bioavailable $\mathrm{Fe}$ and $\mathrm{Zn}$ in seawater.

Comparison of bioaccumulation factors for $\mathrm{Pb}$ and $\mathrm{Cd}$ in zooplankton from the Bay of Bengal showed a 4- and 3-fold higher concentration than in Arabian Sea zooplankton, although the dissolved $\mathrm{Pb}$ and $\mathrm{Cd}$ concentrations were 2.4 and 2.6 times lower, respectively, in the bay than in the sea. Thus, the slight enrichment of $\mathrm{Cd}$ and $\mathrm{Pb}$ concentration (1.13 and 1.63 times) in zooplankton from the Bay of Bengal compared to its metal enrichment in zooplankton from the Arabian Sea may be due to the high bioaccumulation factor of this element existing in the Bay of Bengal zooplankton. Similarly, comparison of bioaccumulation factors for $\mathrm{Ni}$ and $\mathrm{Cu}$ in zooplankton from the Bay of Bengal showed concentrations 1.89 and 1.73 times higher, respectively, than in the Arabian Sea zooplankton, although the concentration of dissolved $\mathrm{Ni}$ lies within the same range in both areas and the dissolved $\mathrm{Cu}$ concentration was 1.3 times lower in the bay than in the sea. Thus, 1.6-times enrichment of $\mathrm{Ni}$ concentration and 2.2-times enrichment of $\mathrm{Cu}$ concentration in zooplankton from the Bay of Bengal are likely to be due to high bioaccumulation factor of these elements in bay zooplankton.

However, the bioaccumulation factor of $\mathrm{Co}$ in zooplankton did not change appreciably in both areas although the dissolved Co concentration in the Arabian Sea was 3.3 times lower than in the Bay of Bengal. Also, comparison of the bioaccumulation factor for Co during this study of Bay of Bengal zooplankton with the report mentioned above was 3.2 times higher. The 1.7-times higher enrichment of Co concentrations in zooplankton from the Bay of Bengal compared with the Arabian Sea may be due to bioavailability of $\mathrm{Co}$ in the surface layers of the Bay of Bengal.

From this study it is clear that the sequence of average metal levels in zooplankton from both the Arabian Sea and Bay of Bengal follows the same order for $\mathrm{Fe}, \mathrm{Zn}, \mathrm{Cu}, \mathrm{Ni}$ and $\mathrm{Pb}$ and not for $\mathrm{Cd}$ and Co. Further, the average metal levels in zooplankton from the Bay of Bengal showed relative enrichment when compared with Arabian Sea zooplankton. However the sequence 
of bioaccumulation factors for all elements except $\mathrm{Fe}, \mathrm{Cu}$, and $\mathrm{Pb}$ varied for both the Arabian Sea and Bay of Bengal zooplankton. The bioaccumulation factors for all the elements in zooplankton except Co are lower in the Arabian Sea compared with the Bay of Bengal. The metal content in zooplankton and bioaccumulation factors will vary appreciably with all elements except $\mathrm{Fe}, \mathrm{Cd}$, and $\mathrm{Pb}$ in the Arabian Sea. Similarly, the metal content in zooplankton and bioaccumulation factors will vary with elements such as $\mathrm{Cd}$ and $\mathrm{Cu}$ in the Bay of Bengal. This points to the importance of bioavailability of metals in seawater as well as differences in the potential of heavy metal accumulation in zooplankton organisms from the Arabian Sea and Bay of Bengal. The trace metal enrichment of $\mathrm{Fe}, \mathrm{Zn}, \mathrm{Cd}, \mathrm{Ni}, \mathrm{Cu}$, and $\mathrm{Pb}$ in zooplankton is likely to be due to the high bioaccumulation factor of these elements in the Bay of Bengal zooplankton, whereas the slight Co enrichment is due to the potential bioavailability of Co in seawater. The bioavailability of Co results from the ability of zooplankton to accumulate and retain Co-cobalamine preferentially over inorganic $\mathrm{Co}$ from the seawater (Nolan et al., 1992).

Further, a comparison of bioaccumulation of metals in zooplankton from the Arabian Sea and the Bay of Bengal reveals that $\mathrm{Fe}$ is bioaccumulated more than any other metal; $\mathrm{Zn}$ and $\mathrm{Cd}$ showed a similar enrichment, and least for $\mathrm{Pb}$.

In general, the non-essential element $\mathrm{Cd}$ was usually taken up at a higher rate than the essential element $\mathrm{Cu}$ under study in the Arabian Sea and Bay of Bengal. The occurrence of $\mathrm{Zn}$ in marine environment is immediately reflected in the $\mathrm{Zn}$ levels in zooplankton, which in fact is concentrated more effectively than $\mathrm{Cu}$. High accumulation of $\mathrm{Zn}$ in zooplankton may be due to coprecipitation of $\mathrm{Zn}$ with calcium carbonate. It is, however, apparent that the trace metal accumulation by zooplankton does not depend only on the soluble fraction in water. The accumulation of non-essential elements to such high levels in zooplankton inhabiting the aquatic system is yet to be fully understood. It is likely that for essential elements like iron, the endogenous or exogenous ligands or chelating agents combine with the metal ions to form soluble complexes and are probably transferred into the cell (Saltman, 1965).

\section{Conclusions}

Because food items of zooplankton (phytoplankton) as well as the zooplankton itself are carried by water currents over significant distances, metal concentrations can only be related to spatial variations on a larger geographic scale. From this study, one can infer that a better understanding of background information is needed on trace metal concentrations with respect to space and time and their fluctuations in the Arabian Sea and Bay of Bengal zooplankton. Without a sound knowledge on spatiotemporal fluctuations, it will be impossible to differentiate anthropogenic metal inputs from natural background concentrations with a routine biomonitoring program. Nevertheless, this study can be looked upon as a starting point for further investigations on these processes.

\section{Acknowledgement}

We are grateful to the Director, Dr. S. R. Shetye, National Institute of Oceanography, Goa, for providing facilities for the study. We thank Department of Ocean Development, New Delhi, for the financial support to the Marine Research-Living Resources Assessment program funded by the Centre for Marine Living Resources and Ecology (CMLRE), Kochi. This is NIO contribution No. 4182.

\section{References}

Brooks, R. R., Presley, B. J., and Kaplan, I. R. 1967. APDC-MIBK extraction system for the determination of trace elements in saline waters by atomic absorption spectrophotometry. Talata 14:809-816.

Chen, C. Y., Stemberger, R. S., and Klaue, B. 2000. Accumulation of heavy metals in food web components across a gradient of lakes. Limnology and Oceanography 45:1525-1536.

Couture, P., and Kuman, P. R. 2003. Impairment of metabolic capacities in copper and cadmium contaminated wild yellow perch (Perca flavescens). Aquatic Toxicology 64:107-120.

CPCB. 1996. Pollution potential of industries in coastal areas of India. In Coastal Pollution Control Series: COPOCS/9/1995-96. 1-83. New Delhi, India: Central Pollution Control Board.

Gajbhiye, S. N., Vijayalakshmi, R. Nair., Narvekar, P. V., and Desai, B. N. 1985. Concentration and Toxicity of some metals in zooplankton from near shore waters of Bombay. Indian Journal of Marine Sciences 14:181183.

George, M. D., and Kureishy, T. W. 1979. Trace metals in zooplankton from the Bay of Bengal. Indian Journal of Marine Sciences 8:190-192.

George, M. D., Sawkar, K., and Reddy, C. V. G. 1984. Determination of $\mathrm{Cd}, \mathrm{Pb}$ and $\mathrm{Cu}$ in Mandovi estuary by differential pulse anodic stripping voltammetry. Indian Journal of Marine Sciences 13(2):64-68.

Hutchins, D. A., Wang, W. X., and Fisher, N. S. 1995. Copepod grazing and the biogeochemical fate of diatom iron. Limnology and Oceanography 40:989-994.

Kleppel, G. S. 1993. On the diets of calanoid copepods. Marine Ecology Progress Series 99:183-195.

Martin, J. H., and Knauer, G. A. 1973. The elemental composition of plankton. Geochimica et Cosmochimica Acta 37:1639-1653.

Muraleedharan, P. M., Ramesh Kumar, M. R., and Gangadhara Rao, L. V. 1995. A note on poleward undercurrent along the southwest coast of India. Continental Shelf Research 15:165-184.

Nolan, C. V., Fowler, S. W., and Teyssie, J. L. 1992. Cobalt speciation and bioavailability in marine organisms. Marine Ecology Progress Series 88:105-116.

Parulekar, A. H., Ansari, Z. A., and Ingole, B. S. 1986. Effect of mining on the clam fisheries and bottom fauna of Goa estuaries. Proceedings of the Indian Academy of Sciences 95(3):325-340.

Prasanna Kumar, S., Jayu Narvekar., Ajoy Kumar, et al. 2004. Intrusion of the Bay of Bengal water into the Arabian Sea during winter monsoon and associated chemical and biological response. Geophysical Research Letters 31:L1504, doi: 10.1029/2004 GL020247.

Raman, A. V., and Ganapati, P. N. 1983. Pollution effects on ecobiology of benthic polychaetes in Visakhapatnam Harbour (Bay of Bengal). Marine Pollution Bulletin 14:46-52.

Rejomon, G. 2005. Biogeochemistry of trace metals in the Indian EEZ of the Arabian Sea and Bay of Bengal. Doctoral Thesis, Cochin University of Science and Technology, India.

Rengasamy, A., and Jing, Z. 2005. Comparative studies on trace metal geochemistry in Indian and Chinese rivers. Current Science 89(2):299309.

Saltman, P. 1965. The role of chelation in iron metabolism. Journal of Chemical Education 42:682.

Shankar, D., Vidya, K., and Shetye, S. R. 2004. A quantitative framework for estimating water resources in India. Current Science 86(4):543552. 
Shetye, S. R., Gouveia, A. D., Shankar, D., et al. 1996. Hydrography and circulation in the western Bay of Bengal during northeast monsoon. Journal of Geophysical Research 101(C6):14011-14026.

Someswara Rao, N., and Venkateswara Rao, T. N. V. 1989. Ground water pollution through seepage of zinc smelter effluents in Vishakapatnam city. Indian Journal of Environmental Protection 9:285-288.
Sundar, D., and Shetye, S. R. 2005. Tides in the Mandovi and Zuari estuaries, Goa, west coast of India. Journal of Earth System Science 114(5):493503.

Zingde, M. D. 1999. Marine Pollution-What are we heading for? In Ocean Science Trends and Future Directions, ed., Somayajulu, B. L. K. 229-246. New Delhi, India: Indian National Science Academy. 